\title{
類型比較を通してみた砥波平野における村落構成の共通原理 \\ 一砥波散居村における居住特性の分析 その 5 -
DWELLING SYSTEMS IN THE TONAMI PLAIN THROUGH A COMPARATIVE STUDY OF THREE DIFFERENT TYPES OF VILLAGES

A spatial analysis of dwelling system in the Tonami Plain Part 5

\author{
黒野弘靖*，菊地成朋** \\ Hiroyasu KURONO and Shigetomo KIKUCHI
}

\begin{abstract}
In this study we made clear the spatial composition of villages in the Tonami Plain by comparison among a dispersed village, a row shaped village and a street village. We realized that for all villages the direction in which water flowed was a primary regulating factor relating to things from housing to the homesteads and village composition. There were also farm lands directly connected to the homesteads in all villages . We defined the unit as "living field". The relationship between a watercourse and a living field was the same in all types of villages. The watercourses flowed along the boundaries of the living field. It meant the three villages were based on the same model.
\end{abstract}

Keywords: Comparative study, Spatial Composition, Street, Watercourse, Living field, Facing to the street 比較研究, 空間構成, ミチ, 水系, 生活領域, 表示性

1.はじめに

本編は、砥波平野の村落を個と集合のしくみとして分析する一 連の研究の続編である。ここでは既に述べた研波平野の村落形態の 分類1の中から「散村」「列状村」「街路村」をとりあげ、そのケー ス・スタディを比較検討する。それにより各村落類型の共通点を把 握し、村落形態によらない平野全域にわたる基本的構成原理の存在 を明らかにする。そして、同一の気候・地勢条件の中にこうした村 落形態のバリエーションが存在する理由を把握する。既報で述べた ように、砺波平野には散居と異なる形態の村落も数多く見いだされ る。本編ではそれらの中から、「散村」の事例としてく天正＞2)を、 「列状村」の事例としてく東開発〉3) 、街路村の事例としてく増山 >4)をとりあげ、それぞれの居住特性を比較する。ここで居住特性 とは、集落・屋敷・間取りのシステム的な対応関係を指し、これに は計画設定や居住者の働きかけが含まれるものとする。今回、事例 としてとりあげた散村と列状村と街路村は、いずれも 18 世紀中頃 に村立てされたことがわかっているう。そこで、こうした近世の計 画が果たしてきた役割を検証することを課題に含めた。なお、現地 調查は、1990 年 10 月から 1995 年 11 月にかけておこなった。

\section{2. 間取りの比較検討}

砺波平野の散村では、主屋は東を向き、その平面は、入口の右側
に土間や台所が来万右勝手の間取りとなっている(図 2 左)。列状 村く東開発〉でも、すべての主屋は東向き、右勝手に揃っている (図 2 中左)。ところが、街路村く増山＞では、約半数にあたる街

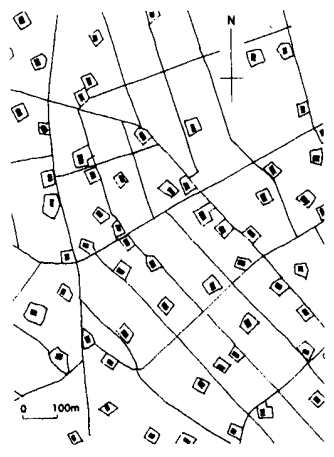

散村 $<$ 天正 $>$

๒:1つの屋敷を示す

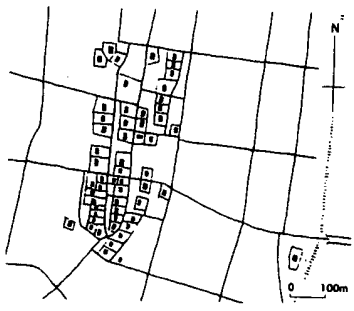

列状村 $<$ 東開発 $>$

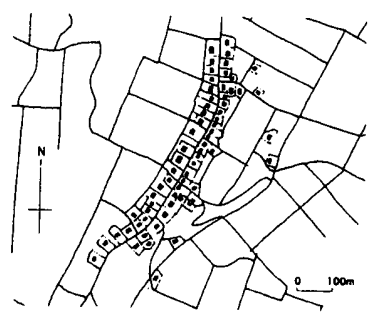

街路村〈增山>

\section{图 1 比較の対象とした村落の形態}

* 新潟大学工学部建設学科 助教授 - 博士 (工学)

** 九州大学大学院人間環境学研究院 教授. 工博
Assoc. Prof., Dept. of Architecture, Faculty of Engineering, Niigata Univ., Dr. Eng. Prof., Faculty of Human-Environment Studies, Kyushu Univ., Dr. Eng. 


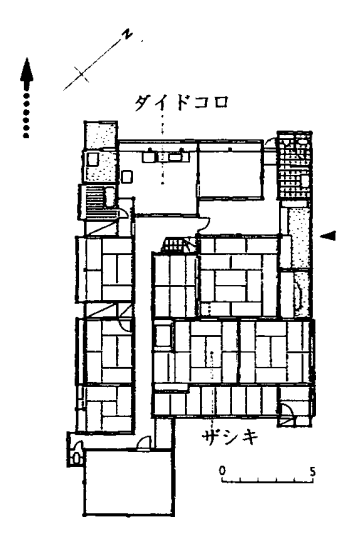

散村 $<$ 天正 $>$ No.7

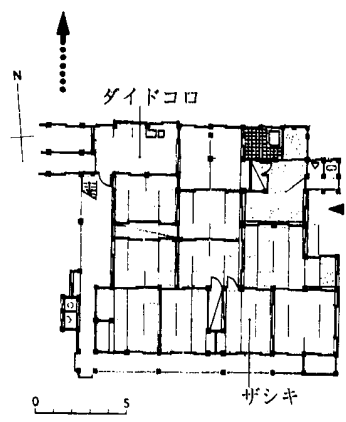

列状村 $<$ 東開発 $>$ No.24

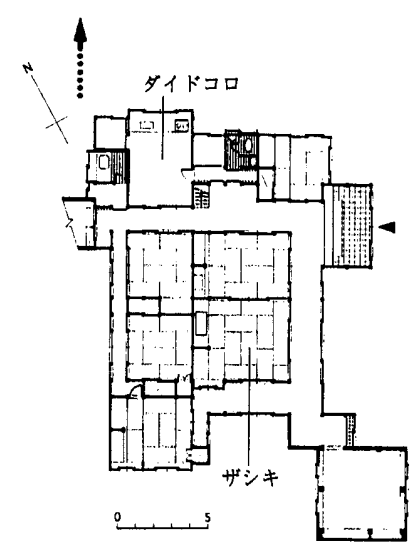

街路村〈増山> 東向き No.68

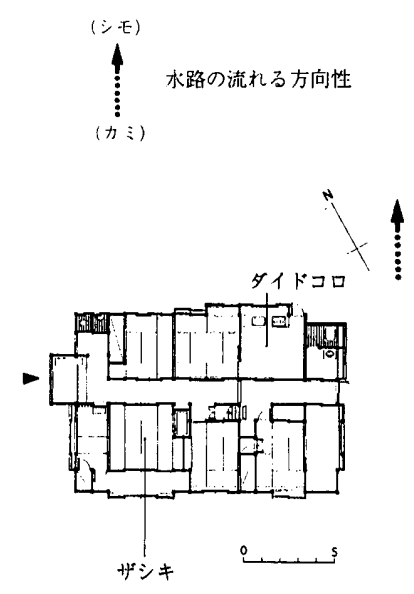

街路村＜増山＞西向き No.22

図 2 間取りと方位と水路の流れる方向との関係

道の東側の住宅が西を向いている（図 2 右)。これは、南北に集落 を貫く街道に入口を向けた結果と捉えられる。さらにこの西向き住 宅は、左勝手となっている(図 2 右)。これは、南から北へ流れる 水路のカミ・シモに、ザシキとダイドコロの位置を対応させたこと を示している。つまり、集落の中で間取りを揃えることよりも、水 の流れの方向性を優先させているといえる。この原則は、当然、散 村や列状村でも守られている。このように形態の異なる村落と比較 することにより、散村の間取りが東を向くことではなく、水の流れ る方向を第一の原則としていると理解できる。

\section{3 . 屋敷構えの比較検討}

ここで屋敷構えの構成要素を一つずつ取り上げ、その配置を村落 ごとに比較し、相違点と共通点を明らかにする。

3. 1 屋敷林（カイニョ）

散村く天正〉では、屋敷の 4 周に植えられている (図 3 左)。こ れにより屋敷がランドマークとなり、点在性が強調されている。

列状村く東開発〉では、個々の屋敷はカイニョを北側に持たない (図 3 中)。しかし、敷地が南北に隣接することにより、北側が補 われ 3 方を囲われているのと同じ効果を得ている6)。つまり、並び を構成することではじめて屋敷としての単位性が獲得される。

街路村く増山〉の屋敷林（カイニヨ）は、主屋の 4 周近くに密に 植えられている(图 3 右)。屋敷が街道に沿って並ふため、前面の 屋敷林が連続し、街道は並木道の景観を呈している7。
このように列状村や街路村では、集合を前提として屋敷林が位置 づいており、屋敷構えが集落の単位として意味を持っている。こう した構成要素の組織化をユニット化と呼ぶことにする。

\section{2 納屋（ナヤ）}

散村＜天正＞では、ナヤが屋敷のマエ側かつシモ側（ウラ）に配

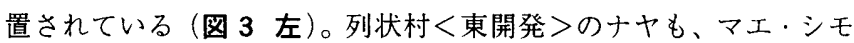
の位置にある（図·3 中）。しかし、街路村〈增山＞のナヤは、屋敷 のセド側かつシモ側に配置されている（図 3 右）。

また、列状村のナヤの外装は、多くがクラと同じ漆喰塗り込め仕 上げとなっている。列状村く東開発＞では、クラがマエ側にないた めに、ナヤが代わりに表示性を担ったものと解釈できる。

また、列状村や街路村では、ナヤの位置が各屋敷で揃っているた め、屋敷の前庭（列状村）や後庭（街路村）が隣家のナヤで囲われ るかたちとなっている。これは屋敷林と同じユニット化といえる。

\section{3 倉（クラ）}

散村く天正>では、クラが屋敷のマエ側かつカミ側に配置される (图 3 左)。一方、列状村 <東開発 $>$ や街路村 <増山 >では、七ド. シモに配置されている（図 3 中・右）。列状村や街路村の敷地は、 間口が狭く奥行きが長い。この敷地形状に合わせてクラをセド側に 移したものと解釈できる。とくに街路村のクラは、主屋のダイドコ 口と渡り廊下でつながり、主屋と同じ下見板張りで覆われており、 外観的には、クラとしての表示性をもたない。

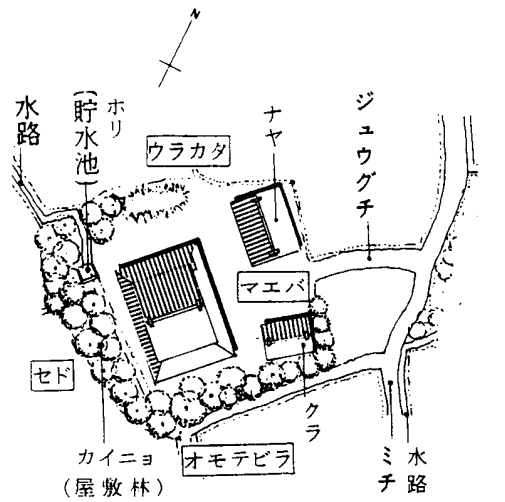

散村 $<$ 天正 $>$ No.7 (围場整備前)

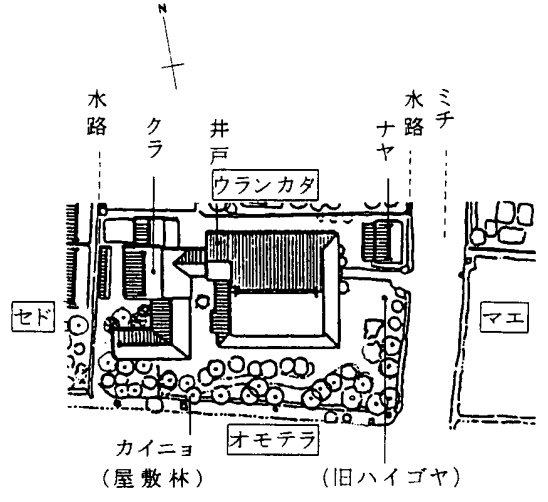

列状村 $<$ 東開発 $>$ No.24

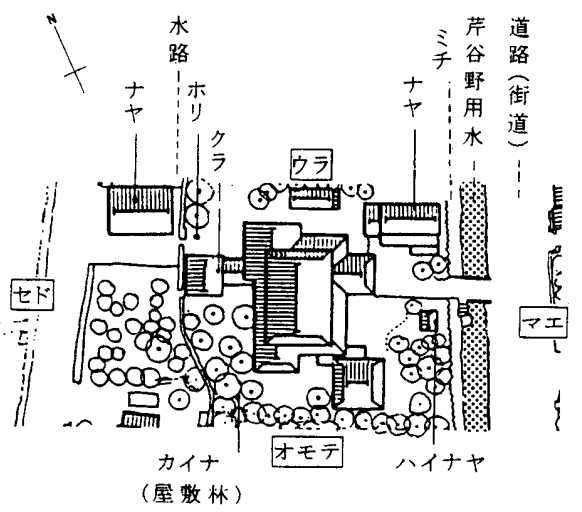

街路村＜増山＞No.68

図 3 屋敷構えの構成要素 


\section{4 灰小屋（ハイゴヤ）}

散村く天正〉では、ハイゴヤが屋敷のマエにあったという。围場 整備の際にとりこわされて、現存しない。列状村く東開発〉では、全 58 軒中の 19 軒に見られ、多くが宅地のマエかつカミ側にある（図 3 中)。屋敷のマエ側には、水路や耕地が広がっているため、防火 や施肥の点で都合がよい。街路村く増山>でも、全 72 軒中 22 軒に 見られ、これらはマエ側かつカミ側にある（図3右）。たたし街路 村の水路や耕地は、屋敷のセド側にあるので、このハイゴヤの位置 は、防火や施肥に有利とはいえない。その理由は表示性と考えられ る。すなわち街路村においては、ナヤやクラがミチに面さないため、 八イゴヤをマエ側に配置し、屋敷の表情としていると解釈できる。 実際に街路村く增山>のハイゴヤは技術を凝らしてつくられており、 「ハイナヤ8」」と呼ばれている。

\section{5 石垣（ハドリ）}

散村く天正＞では、屋敷のマエ側、セド側、カミ側の 3 方に回す ことを原則としている。庄川の付近に立地する屋敷では、カミ側を とくに高くして溢流水に備えた例も見られる。列状村く東開発〉で は、ハドリが屋敷のマエ側（庄川に近い側）だけになっている。街 路村く増山〉では、屋敷のセド側に見られる9。

このように列状村や街路村の屋敷には、ハドリが1辺にしかない。 しかし、屋敷が並ふことにより、ハドリがミチ沿いに連続する。そ して、集落レベルでのミチのデザインが成立している。

\section{6 眝水池（ホリ）}

散村く天正〉では、屋敷のセド側かつウラ側にある（図 3 左）。 これは主屋のダイドコロに面しており、その水は生活・飲料用とし て使われた。街路村く增山〉でも、ホリ（貯水池）は屋敷のセド， ウラ側にある(図3 右)。つまり、ホリは、ダイドコロに近いカワ （水路）沿いに設置されているといえる。

\section{7 構成要素の配置を通してみた原則}

以上の分析により、屋敷の構成要素の相違点や共通点を生む要因 として、つぎの三つを指摘できる。これらは居住者が住みこなす過 程で蓄積した原則と捉えられる。

1. 隣接関倸の利用 列状村や街路村の屋敷林やナヤは、屋敷が隣 接することを前提として、各屋敷の環境が完結するかたちになって いる。また、その石垣は、一辺だけにつくられるものの、屋敷が並 ふことによりミチ沿いに連続する。このようにユニット化している。

2. 表示性 列状村のナヤが漆喰塗り込め仕上げとなっていること、 および街路村の灰小屋が凝ったつくりとなってマエ側に配置されて いることは、屋敷のマエ側に対する表示性を示している。

3、間取りとの対㐫 眝水池（ホリ）の位置は、いずれの村落に おいても変わらない。これは、主屋のダイドコロとの関連が強いた め、その位置が定まっているものと考えられる。

\section{4. 集落の構成と屋敷構えとの対応}

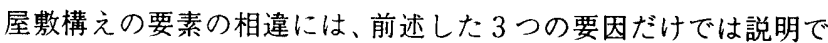
きない事象がある。これを集落構成との対応から説明する。

\section{1「イエの領域」の広がり方}

村落形態ごとに、1 軒の所有する生産耕地の広がり方をみる（図 4 )。散村<天正>では、屋敷と連続して所有する水田のほかに、1 筆単位で分散する水田を持っていた。屋敷まわりの水田をコシメグ ラ、離れた水田をトオタンボと呼び区別している（图４上）。

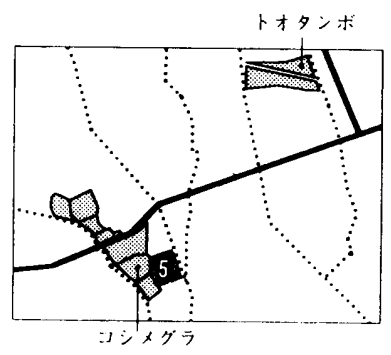

散村 $<$ 天正 $>($ No.5)

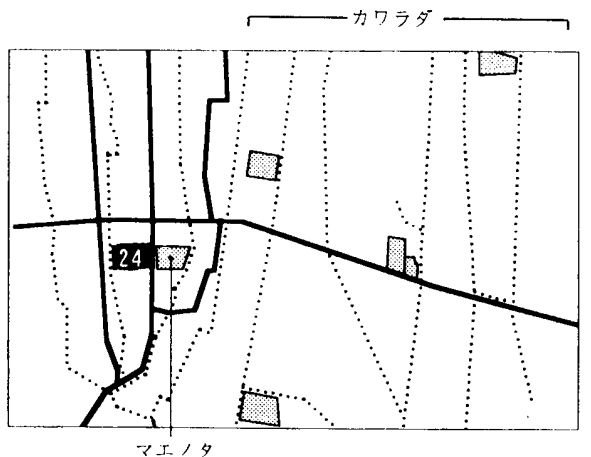

列状村

<東開発 $>$

(No.24)

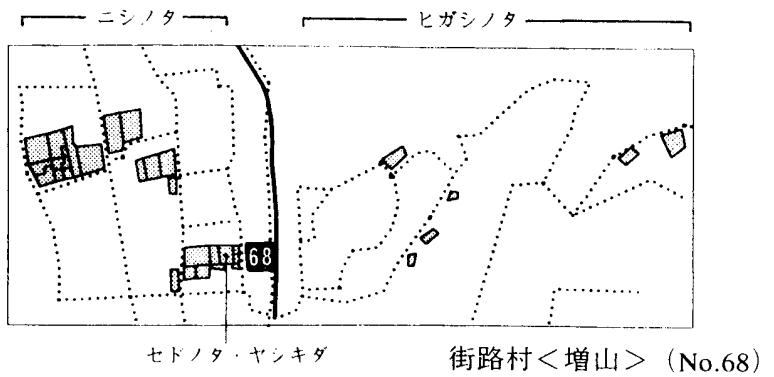

図 41 軒の領域モデル

列状村＜東開発＞では、屋敷の東側に連続して「マエノ夕」を、川 沿いに1筆単位で分散する「カワラダ」を持っていた（图 4 中)。

街路村く増山＞では、屋敷のウラ側に連続して「セドノタ(ヤシ キダ)」を持ち、離れたところに「ヒガシノタ」・「ニシノタ」と呼ば れる耕地を持っていた（図 4 下）。

このように、どの村落形態においても、1軒の生産耕地は、屋敷 と連続したものと、屋敷から離れたものとの二つがある。とくに屋 敷と連続した耕地は、固有の呼び名を持ち、苗代や肥沃な土(ドロ) をつくる場所となっていた。こうした宅地と連続した耕地という原 則は、砺波平野の村落全体に共通する、耕地所有のモデルといえる。 そして、村落景観の形成にとって、この屋敷と連続する耕地の存在 は、きわめて大きい。散村の場合、この耕地が宅地の周囲をとりま くことにより宅地間の距離が保たれている。列状村の場合、この耕 地が宅地のマエ側に揃うことにより、屋敷の並びの間に「マエノ夕」 の層ができ、列状の構成がはっきりとわかる。街路村の場合には、こ れが宅地のセド側に揃うことにより、屋敷林の位置を主屋付近に限 定し、周辺の水田地帯との区分を明確にしている。

この宅地と連続した耕地は、屋敷構えの構成要素の位置にも影響 している。ナヤは、散村と列状村で屋敷のマエ側、街路村でセド側 にある。これは、街路村の宅地と連続する耕地の広がり方と対応す るものとなっている。つまり、宅地と連続する耕地に近いところに、 農作業と関わりの深いナヤが配置されている。 


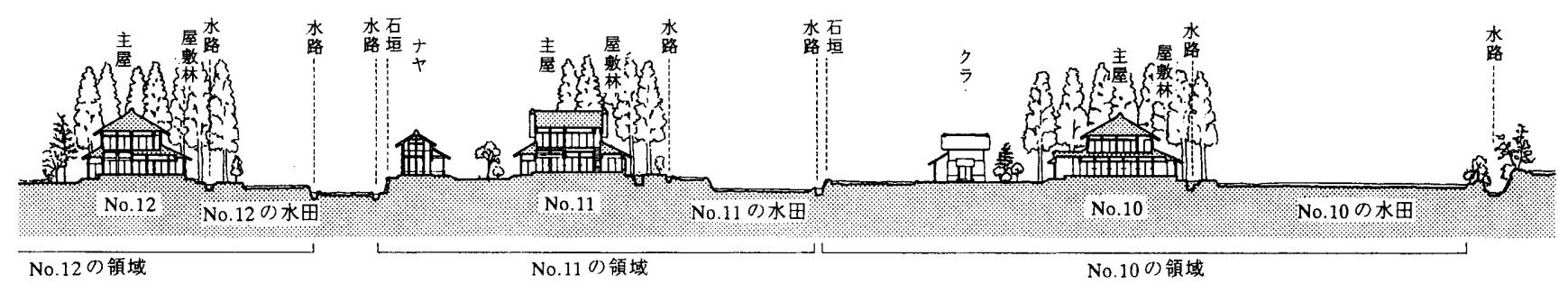

散村 $<$ 天正 $>$ (围場整備前)
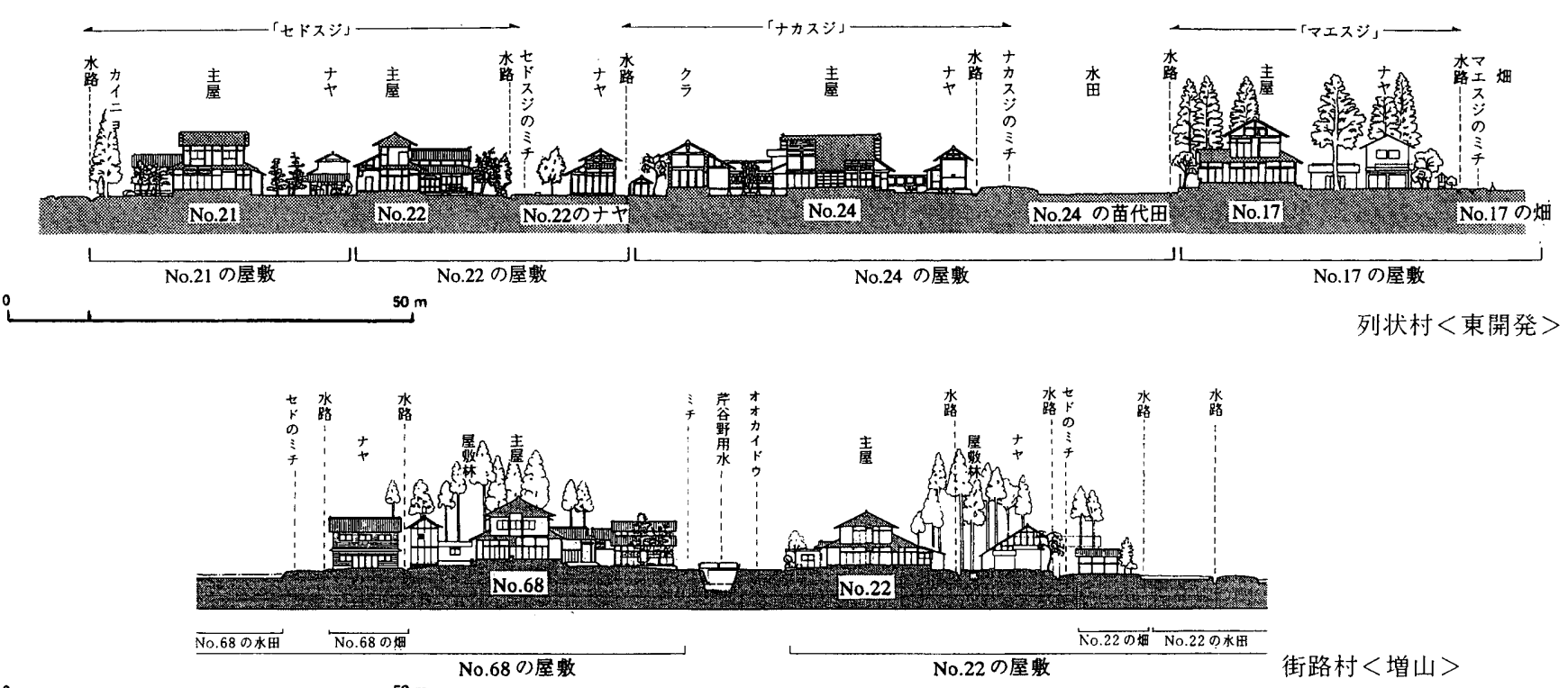

$50 \mathrm{~m}$

図 5 「イエ」の領域と水路やミチとの関わり

4.2「イエの領域」と水路との対応

水路（カワ）は、屋敷構之の構成要素の位置に大きな影響を及ほ している。まず何より、要素の位置は、水路の流れる方向（力ミ. シモ）を根拠に決まっている。さらに要素の中には水路と関わりが 深いものがある。貯水池（ホリ）は、水路沿いかつ主屋の七ド側（ダ イドコロに近いところ）に設けられる。つまり水路は、ホリを介し て主屋のダイドコロと接続している。

つぎに、水路と「イエの領域」との対応を見る（図 5 ）。

围場整備前の散村く天正>の水路は、網の目状に見える。しかし、 これを各戸の「イエの領域」と重权合わせてみると、その領域の境 界を流れるものと、領域内を通り屋敷を束ねて流れるものとに区分 できる（図 5 上）。このうち領域内の水路は、つねに主屋の七ド側 を通り、そこには貯水池（ホリ）がつくられ、生活・飲料用の水源 として利用されていた。

列状村＜東開発＞の水路は、直線的に流れている。「イエの領域」 と重ね合わせてみると、領域の内側を通る水路と、領域の境界を通 る水路とに区分できる（図 5 中）。領域の内側を流れる水路は、ミ チと対になって、屋敷のマエ側を束枋るように流れている。一方、境 界を流れる水路は、屋敷の七ド側のクラに面したところと、マエ側 の耕地（苗代田や畑）の端を流れている。

街路村<增山>の水路は、長く直線的に通っている。「イエの領 域」と対応させてみると、マ工側の境界に芹谷野用水が通り、セド
側の境界に水路が通っている（図５下）。さらに「イエの領域」の 内側の、主屋の七ド側にも、屋敷を束ねて流れる水路がある。

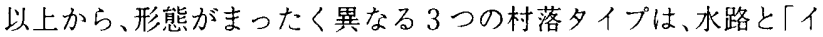
エの領域」との対応に注目すると、同じ構成をもっているといえる。 すなわち「イ工の領域」の境界を流れる水路と、その領域の内側を 流れる水路との 2 種類がある。また、内側を流れる水路に沿って、 洗い場や眝水池が設置されている。さらに「イエの領域」は、主屋 に対して、屋敷を束ねる水路の側に広がっている。

列状村＜東開発＞や街路村＜増山＞の水路は、「イ工の領域」の境 界上も内側も、長く直線的である。この事実は、列状村や街路村の 設立時に、計画設定があったこと、そして、計画の際に宅地と連続 した耕地を含めた「イエの領域」が単位となっていたことを示して いる。また、どの村落形態においても、主屋の七ド側に水路が流れ ていることから、主屋のセド側にダイドコロがくるという間取りや、 水路にホリを設けて飲料水をダイドコロに運ふという生活が想定さ れていたと考えられる。

\section{3 ミチと屋教構えとの対応}

つぎに、それぞれの村落におけるミチの通り方を屋敷構えとの対 応に注目して分析する。

散村く天正>の固場整備前のミチは、網の目状に屋敷をつないで いるように見えるものの、その利用に注目すると、主屋正面に向か うアプローチ路と、村落内のカミ・シモを結ぶ主要なミチと、町へ 
と続く街道とに区分できる10)。

列状村<東開発>のミチは、屋敷の並びに沿って、マエスジ、ナ カスジ、セドスジの 3 本ある(図 5 中)。「イエの領域」との関係 に注目すると、 3 本ともその内側を水路に沿って通っていることが わかる。領域の境界上には、水路が通るだけで、ミチはない。

街路村く増山>のミチは、芹谷野用水沿いの両側に通っている (図 5 下)。このうち一方は、「カイドウ(街道)」と呼ばれていた。 また、主屋のセド側に、屋敷を束ねて流れる水路に沿って、セド， ミチと呼ばれるミチがある。「イ工の領域」との関係に注目すると、 領域の内側で、宅地と畑の境界にあたるところに、セドノミチが 通っている。これは日常の集落内の行き来に使われている。

以上のように、「イエの領域」との対応からミチの構成を見ると、 $3 つ の$ 村落の共通点として、「イ工の領域」の内側を通るミチの存在 を指摘できる。これは屋敷を束ねる水路と対になり、屋敷と耕地の 間を通り、集落内の移動に使われている。围場整備前のミチは、人 が通る幅しかなく、舗装されているわけでもなかった。しかし、村 落ごとの屋敷構えの相違は、主としてこのミチ側に生じている。

まず、散村では、集落内移動に使われるミチからアプローチ路が 延び、その先に屋敷林を背景とした主屋、クラ、ナヤの構えが正面 を向けていた。つぎに列状村では、集落内移動に使われるミチに面 した側だけにハドリが連続し、ナヤが漆喰塗り込め仕上げとなって いる。さらに街路村では、集落内移動に使われるミチに面したとこ ろに洗い場や貯水池が設置されている。このように散村と異なる形 態をとった場合も、その屋敷はミチに面した構成要素を変化させて おり、ミチは屋敷が働きかける対象となっているのである。こうし た屋敷の内側からの論理により構成要素が変化した部分において、 村落ごとの景観の違いが生まれ、村落の個性ができあがっている。 列状村く東開発〉のミチは、端的にこうしたミチの性格を表して いる。それは「イエの領域」の内側を通っているのである。これは ミチが私的な領域の中にありながら、利用においては集落という社 会に供することを認められていたことを示している。ミチが屋敷の 側から動きかける対象となり得たのは、このような所有と利用の関 係があったためと考えられる。

\section{5 形態の異なる村落の共存}

砺波平野では、同一の気候・地勢条件の中に、散村や列状村や街 路村という村落形態のバリエーションが見られる。地理学分野の研 究では、このうち集村の起源が古いとされている。しかし、これま での検討により、散村と列状村と街路村の成立は、いずれも同じ近 世前期とわかった。そして、屋敷構えと集落構成を分析した結果、列 状村や街路村が集村化している理由は、地理的条件よりも計画性に よるものと把握できた。

近世の砺波平野では、旧河床の開拓が散居を前提として進められ た。散居は、計画者にとって小資本で継続的に新田開発を進めるこ とができ、居住者にとっては生産活動を空間的に自立したものにす ることができる、双方にとって利点のある計画となっていた。さら に散居は、固定的な計画ではなかった。そのため居住者が働きかけ る余地のあるものとなっていた。水路が「イエの領域」の境界とな ク、ミチに段階性が生じ、屋敷構之が水路の方向によって秩序づけ られていった。一方、列状村や街路村では、より強い計画性が働い た。これは直線的な水路や矩形の敷地割りに認められる。ただ、散
村と同様の「イエの領域」が確認されること、その位置を考慮して 水路やミチが設定されていることから、居住のモデルは、散村と共 通していたことがわかる。列状村は、河川に近く、洪水に対する危 険があった。それに対処するため、散村とほぼ同じモデルのまま、水 路のカミ・シモ方向に「イエの領域」を切り詰めて、隣接させたか たちと捉えられる。そこでは、居住者による働きかけとして、屋敷 林やハドリ（石垣）のユニット化が見られる。洪水対策上重要な要 素を相互負担し、集落景観の主眼としていることがわかる。

また、街路村は、段丘上に立地し、水源が一つの用水に限られて いた。こうした立地条件に対応するため、屋敷を用水の両側に向か い合うように並べ、セド側だけに耕地が広がるという、かなり変形 した「イエの領域」モデルを採用している。ここでも、居住者は、そ の設定に対応して、屋敷林やハイナヤを芹谷野用水沿いに集中させ、 街道沿いの並木道という集落景観を作り出している。

以上で見てきたように、村落のしくみ自体は、共通する原理に基 づいている。一方、各村落で集合のための理由は異なっている。そ れに対して、計画設定と居住者による働きかけがなされることによ り、村落ごとの固有の景観がもたらされているのである。そして、現 在のような異なる村落の共存する状況が生み出されたと考えられる。 謝辞

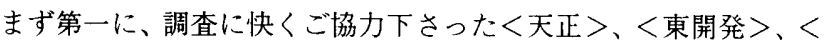
増山>の方々にお礼を申し上げたい。また、研究を進めるにあたり、 研波市郷土資料館の佐伯安一氏・新藤正夫氏、庄川町教育委員会の榎 木淳一氏、井波町教育長の吉藤一郎氏、井口村の塚崎正一郎氏に、多 大なお力添えを戴いた。そしてこの研究は、実測調查を含めて、鈴木 成文 (神戸芸術工科大学)、伊藤裕久 (東京理科大学)、小川曉子. 金 子裕子. 斎藤朝秀. 大沼徹 (当時: 東京大学)、佐伯仂可・横井普. 石塚勝広・伊藤司（当時：新潟大学）の各氏と共同しておこなったも のである。ここに東心よりの感謝の意を表したい。

\section{参考文献および注}

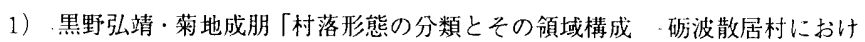
る居住特性の分析その1·日本建築学会計画系論文集，第477号，1995华 11 月, pp. 117-124。

2）黑野弘靖・菊地成朋「村落と屋敷の対応関係からみた散村の構成原理 ·研 波散居村における居住特性の分析その 2 」日本建築学会計画系論文集，第 507 号, 1998 年 5 月, pp. 151-155。

3）黑野弘靖・㐘地成朋「列状村の集落空間とその水系・ミチへの連関 - 砺波 散居村における居住特性の分析その3-」日本建築学会計画系論文集, 第520 号, 1999 年6月，pp. 213-217。

4）黑野弘靖·菊地成朋「街路村における街路と水路の中心性と屋敷構之との関 係 一砺波散居村における居住特性の分析その4-」日本建策学会計画系緰 文集，第 537 号，2000 年 11 月, pp. 165-170。

5）前掲書 1）第 2 節と第 3 節 pp.118-120、前掲書 3）第 2 節 p.214、前掲書 4) 注3) p.170 を参照。

6）前揭書 3）第4.2節の説明と図 4 pp. 214-215を参照。

7）前揭書 4) 第4.1節の説明と写真1 pp. 166-167 を参照。

8）研波地方の建物呼称として、「ナヤ(納屋)」は、「コヤ(小屋)」よりも格が 高いものに使う。

9）街路村は段丘上に立地するので、ハドリは洪水防御の役割をもたない。

10）前掲書 2）第4.1節と第 4.2 節 の説明および図 5 pp.153-154を参照。

(2000年12月 10 日原稿受理, 2001 年 4 月 24 日採用決定) 